\title{
Experimentally extending the spawning season of a marine bivalve using temperature change and fluoxetine as synergistic triggers
}

\author{
Pieter J. C. Honkoop ${ }^{1, ~ ", ~ P i e t e r n e l l a ~ C . ~ L u t t i k h u i z e n ~}{ }^{1,2}$, Theunis Piersma ${ }^{1,2, * *}$ \\ ${ }^{1}$ Netherlands Institute for Sea Research (NIOZ), PO Box 59, 1790 AB Den Burg, Texel, The Netherlands \\ ${ }^{2}$ Centre for Ecological and Evolutionary Studies, University of Groningen, PO Box 14, 9750 AA Haren, The Netherlands
}

\begin{abstract}
Contrary to prediction, a large intraspecific variation can be observed in reproductive timing of free-spawning marine organisms. The relative contributions of heritable genetic differences and phenotypic plasticity to this variation have remained unstudied. To do so would require experimental extension of the natural spawning season in cases where the windows of gamete release do not overlap. We tested the use of the selective serotonin re-uptake inhibitor fluoxetine (the active ingredient of Prozac) to initiate spawning in the marine bivalve Macoma balthica. In 5 experiments we attempted to induce spawning, applying $1 \mathrm{ppm}$ fluoxetine versus a control group to $M$. balthica which were kept in the lab for up to more than a month after the natural spawning season. Both the fluoxetine and the control group received a preceding temperature shock, which is indispensable for the onset of spawning. We conclude that fluoxetine effectively induces spawning in $M$. balthica and helps obtain fertile gametes after the natural spawning season. We discuss the usefulness of fluoxetine as a tool for studying the origin of intraspecific variation in reproductive timing.
\end{abstract}

KEY WORDS: Spawning season - Reproductive timing Marine bivalve Rearing Prozac

In free-spawning sedentary marine organisms the synchrony of the timing of gamete release is crucial to reproductive success. As gametes drift away from their parents, their concentration decreases and so does the probability of fertilization (Brown \& Knouse 1973, Pen-

- Present address: Special Research Centre, Ecological Impacts of Coastal Cities, Marine Ecology Laboratories A11, University of Sydney, NSW 2006, Australia

- Addressee for correspondence: Netherlands Institute for Sea Research, Department of Marine Ecology, PO Box 59. 1790 AB Den Burg, The Netherlands.

E-mail: theunis@nioz.nl nington 1985, Levitan et al. 1991, Levitan 1993). For this reason, individuals of a local population should spawn at exactly the same time. The scale over which such synchronization is observed in the field does not always confirm this prediction. In Macoma balthica timing of gamete release is known to vary with microhabitat (Thompson \& Nichols 1988). Moreover, some free-spawning species appear not to spawn in synchrony even within a patch (Levitan 1988, Babcock et al. 1992). The origin and consequences of intraspecific variation in reproductive timing are well discussed but hardly resolved. Variation in the timing of spawning could result in reproductive isolation (Bush 1975), subsequent population differentiation and, eventually, speciation (Knowlton 1993, McClary \& Barker 1998).

To estimate which part of intraspecific variation in reproductive timing is due to phenotypic plasticity and which part to genetic differentiation, it is necessary to make controlled crosses within and between phenotypes in the laboratory. The latter is impossible when natural reproductive windows of phenotypes do not overlap. In some species (e.g. oysters Ostreidae), artificially increasing the length of the reproductive season can be accomplished by stripping gametes out of ripe gonads (Loosanoff \& Davies 1963). In other species, controlled induction of spawning is the only way to successful fertilization.

In a number of bivalve mollusks, the neurotransmitter serotonin (5-hydroxytryptamine) controls, at least partially, the onset of spawning (Gibbons \& Castagna 1984, Hirai et al. 1988, Ram et al. 1993). One possibility to induce spawning in those bivalves is by administering serotonin (Gibbons \& Castagna 1984). Another possibility is the inhibition of re-uptake of serotonin in synapses using so-called selective serotonin re-uptake 
inhibitors (SSRIs). Although the precise mechanism remains unknown, effects of SSRIs on induction of spawning have recently been demonstrated by Fong (1998) and Fong et al. (1998).

Although serotonin is more widely used as an inducer of spawning, SSRIs are preferable because of their low effective concentration and therefore low costs (Fong 1998). We tested the suitability of the SSRI fluoxetine (N-methyl-3[p-trifluoromethylphenoxy]-3phenylpropylamine, fluoxetine, the active compound of the human prescription drug Prozac) as a tool for studying the origin of variation in reproductive timing in the marine bivalve Macoma balthica (L.) (Tellinidae). In this species a large variation in timing of reproduction can be observed at several scales. At the microhabitat scale, spawning occurs over a time span of a few weeks. Across microhabitats and between geographical sites, spawning occurs from early February until the end of August (Harvey \& Vincent 1989). Two non-overlapping spawning seasons have been reported at 2 southern distributional limits: San Francisco Bay (USA) (Nichols \& Thompson 1982) and the Gironde estuary, France (Bachelet 1980). Some observations suggest delayed spawning in subtidal microhabitats (Harvey \& Vincent 1989, pers. obs.). Günther et al. (1998) even found a bimodal distribution of the presence of pelagic $M$. balthica larvae in the German Wadden Sea with maxima in April/May as well as in the period September to December.

For our experiments, adult mature Macoma balthica were collected at an intertidal mudflat of Balgzand in the southwestern part of the Dutch Wadden Sea. Prior to the expected spawning period, at the end of March or the beginning of April 1998, ca 2000 individuals were collected and transferred to 10 small basins $(1 \times \mathrm{b}$ $\times \mathrm{h}=30 \times 20 \times 6 \mathrm{~cm})$ filled with sediment. The basins were placed in a large storage container $(\mathrm{l} \times \mathrm{b} \times \mathrm{h}=2 \times$ $0.6 \times 0.6 \mathrm{~m}$ ). Fresh sand-filtered sea water was provided at a flow rate of $6 \mathrm{Imin}{ }^{-1}$. The temperature of the streaming sea water was kept at $8.5^{\circ} \mathrm{C}$. Each day the animals were fed with fresh phytoplankton which was collected in the Marsdiep, the tidal channel between Den Helder and Texel. For M. balthica the temperature range at which spawning can be initiated is 7 to $14^{\circ} \mathrm{C}$ (Caddy 1967, De Wilde 1975, Gilbert 1978, Harvey \& Vincent 1989). The time window when these temperatures were reached in the southwestern part of the Wadden Sea and when spawning took place in the source population of $M$. balthica used in our experiments is shown as the shaded area in Fig. 1.

Our first observations and experiences suggested that successful stimulation of spawning could only be achieved if a short 'cooling period' was given just prior to the induction of spawning. The spawning success lexpressed as the percentage of animals releasing

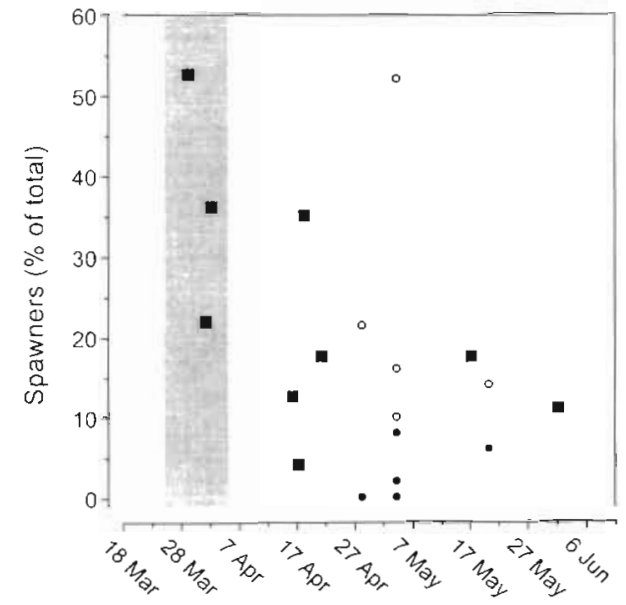

Fig. 1. Macoma balthica. Percentage of mature bivalves that could be induced to spawn in the laboratory using only a sudden increase in water temperature as the trigger (a). The shaded area indicates the spawning period in the field at the place of origin of our experimental animals. The data of the experiment performed to test the effect of Prozac, mentioned in Table 1, can be found in this figure too (temperature treatment control $[\bullet]_{\text {; }}$ Prozac + temperature treatment, [o])

gametes) was consistently low when animals were taken from the storage container (water temperature of $8.5^{\circ} \mathrm{C}$ ) and immediately transferred to a $100 \mathrm{ml}$ beaker containing sea water with a temperature of $12.5^{\circ} \mathrm{C}$ (and thus experiencing a temperature-shock of only $4^{\circ} \mathrm{C}$ ). Thus, to obtain more spawning individuals, 1 to $3 \mathrm{~d}$ before experiments were performed, a group of Macoma balthica was placed in a refrigerator at $4{ }^{\circ} \mathrm{C}$ (about 100 individuals per treatment). After this cooling period the animals were placed individually in $100 \mathrm{ml}$ beakers containing fresh sea water with a temperature of $12.5^{\circ} \mathrm{C} . M$. balthica thus experienced a temperature shock of $8.5^{\circ} \mathrm{C}$. As described by other authors, such a temperature shock can be used as a spawning-trigger (De Wilde \& Berghuis 1978). For more details about the method used see Honkoop \& Van der Meer $(1997,1998)$.

If animals were placed at $4^{\circ} \mathrm{C} 1$ to $3 \mathrm{~d}$ before spawning was initiated, the percentage of spawning individuals amounted to over $50 \%$. Note that this percentage is higher if we discount the occasional (immature or sick) individuals incapable of spawning. Shortly before and during the days of the natural spawning period (the beginning of April, see the time window in Fig. 1), the percentage of individuals that could be triggered to spawn (only using a temperature shock) was relatively high. After an extended storage period, it was more difficult to elicit spawning in mature individuals, and the percentage of spawning individuals remained relatively low (squares in Fig. 1). Although no adequate experiments were performed to specifically study the 
Table 1. The effect of $1 \mathrm{ppm}$ fluoxetine combined with a temperature shock ( $\mathrm{T}+$ Prozac) on the induction of spawning in $M a c o m a$ balthica. The control animals only experienced a temperature shock ( $T$ only). We tested for differences between treatments using a $\chi^{2}$ test

\begin{tabular}{|c|c|c|c|c|c|c|c|}
\hline Date & Treatment & $\begin{array}{l}N \text { adults } \\
\text { tested }\end{array}$ & $\begin{array}{l}N \text { males } \\
\text { spawned }\end{array}$ & $\begin{array}{l}\text { N females } \\
\text { spawned }\end{array}$ & $\begin{array}{l}\text { Percentage spawners } \\
(\% \text { of number tested) }\end{array}$ & $\chi^{2}$-value & $\begin{array}{l}\text { Test for difference between } \\
\text { treatments ( } p \text {-value) }\end{array}$ \\
\hline 28 April & $\begin{array}{l}T+\text { Prozac } \\
T \text { only }\end{array}$ & $\begin{array}{l}56 \\
56\end{array}$ & $\begin{array}{l}5 \\
0\end{array}$ & $\begin{array}{l}7 \\
0\end{array}$ & $\begin{array}{c}21.4 \\
0\end{array}$ & 13.44 & $<0.001$ \\
\hline 4 May & $\begin{array}{l}T+\text { Prozac } \\
T \text { only }\end{array}$ & $\begin{array}{l}50 \\
50\end{array}$ & $\begin{array}{l}5 \\
1\end{array}$ & $\begin{array}{l}3 \\
0\end{array}$ & $\begin{array}{r}16.0 \\
2.0\end{array}$ & 5.99 & $<0.05$ \\
\hline 4 May & $\begin{array}{l}T+\text { Prozac } \\
\text { T only }\end{array}$ & $\begin{array}{l}50 \\
50\end{array}$ & $\begin{array}{l}5 \\
0\end{array}$ & $\begin{array}{l}0 \\
0\end{array}$ & $\begin{array}{c}10.0 \\
0\end{array}$ & 5.26 & $<0.05$ \\
\hline 4 May & $\begin{array}{l}T+\text { Prozac } \\
\text { T only }\end{array}$ & $\begin{array}{l}25 \\
25\end{array}$ & $\begin{array}{l}7 \\
1\end{array}$ & $\begin{array}{l}6 \\
1\end{array}$ & $\begin{array}{r}52.0 \\
8.0\end{array}$ & 19.46 & $<0.001$ \\
\hline 20 May & $\begin{array}{l}\mathrm{T}+\text { Prozac } \\
\mathrm{T} \text { only }\end{array}$ & $\begin{array}{l}50 \\
50\end{array}$ & $\begin{array}{l}5 \\
3\end{array}$ & $\begin{array}{l}2 \\
0\end{array}$ & $\begin{array}{r}14.0 \\
6.0\end{array}$ & 1.77 & $<0.1$ \\
\hline
\end{tabular}

effects of a temperature shock as a spawning trigger (as demonstrated earlier by De Wilde \& Berghuis 1978), we conclude that a 'cooling step' is necessary to stimulate a successful spawning event in the laboratory.

We tested whether fluoxetine, in combination with a temperature shock, was able to induce spawning in Macoma balthica and whether this treatment resulted in higher percentages of spawning individuals than a preceding cooling step alone. A stock solution of fluoxetine was obtained by dissolving the prescription drug Prozac (Eli Lilly) in demineralised water until a final concentration of the stock solution of $20 \mathrm{mg}$ fluoxetine per $100 \mathrm{ml}\left(6.5 \times 10^{-4} \mathrm{~mol} \mathrm{l}^{-1}\right)$. A total of ca 100 individuals of $M$. balthica were, after a storage period at $4^{\circ} \mathrm{C}$ for 1 to $3 \mathrm{~d}$, randomly assigned to individual treatments, and individually placed in a $100 \mathrm{ml}$ beaker containing $50 \mathrm{ml}$ sea water with a temperature of $15^{\circ} \mathrm{C}$. After an acclimation period of $30 \mathrm{~min}$ when most individuals showed pronounced siphonal activity, $1 \mathrm{ml}$ of the fluoxetine stock solution was added. Control groups received $1 \mathrm{ml}$ demineralised water. After $30 \mathrm{~min}, 50 \mathrm{ml}$ fresh sea water with a temperature of $15^{\circ} \mathrm{C}$ was added to each beaker (the total volume of sea water was thus $100 \mathrm{ml}$, and the final fluoxetine concentration was $1 \mathrm{ppm}$ ). The effect of fluoxetine was obvious (Table 1). In 4 of the 5 replicate experiments a significantly higher percentage of individuals spawned in the presence of $1 \mathrm{ppm}\left(3.2 \times 10^{-6} \mathrm{~mol} \mathrm{l} \mathrm{l}^{-1}\right)$ Prozac $\left(\chi^{2}\right.$ test, $\left.p<0.05\right)$, whereas the fifth experiment came close to significance $\left(\chi^{2}\right.$ test, $\left.p<0.1\right)$. Thus, with the help of Prozac it was possible to obtain gametes in May, more than a month after the natural spawning period. The gametes were also fertile, as they led to fertilized eggs and viable larvae (unpubl. data).

Although more experiments may be necessary to optimize the initiation of spawning with respect to the optimal concentration of Prozac, it is clear that Prozac can be used to initiate spawning in marine bivalves just as well as in freshwater bivalves (Fong 1998). The effect of Prozac is most pronounced if a cool period is given before the sudden temperature elevation. The technique will now allow us to study the genetic and functional aspects of reproductive timing in marine bivalves such as Macoma balthica.

Acknowledgements. We thank Jaap van der Meer and Jan Drent for co-ordinating the organisation of this project and for practical help, respectively. The work was supported by a PIONIER-grant to T.P. from the Netherlands Organization for Scientific Research (NWO) and by the NIOZ-research funds of Henk van der Veer and Jaap van der Meer. Chemist's shop 'Zuiderhaaks' in Den Helder gracefully provided Prozac. This is NIOZ-publication 3348

\section{LITERATURE CITED}

Babcock RC, Mundy C, Keesing J, Oliver J (1992) Predictable and unpredictable spawning events: in situ behavioural data from free-spawning coral reef invertebrates. Invertebr Reprod Dev 22:213-228

Bachelet G (1980) Growth and recruitment of the tellinid bivalve Macoma balthica at the southern limit of its geographical distribution, the Gironde estuary (SW France). Mar Biol 59:105-117

Brown GG, Knouse JR (1973) Effects of sperm concentration, sperm age, and other variables on fertilization in the horseshoe crab Limulus plyphemus L. Biol Bull 144:462-470

Bush GL (1975) Modes of animal speciation. Ann Rev Ecol Syst 6:339-364

Caddy JF (1967) Maturation of gametes and spawning in Macoma balthica (L.). Can J Zool 45:955-965

De Wilde PAWJ (1975) Influence of temperature on behaviour, energy metabolism, and growth of Macoma balthica (L.). In: Barnes $\mathrm{H}$ (ed) Proc 9th Eur Mar Biol Symp. Aberdeen University Press, Aberdeen, p 239-256

De Wilde PAWJ, Berghuis EM (1978) Laboratory experiments on the spawning of Macoma balthica; its implication for production research. In: McLusky DS, Berry AJ (eds) Physiology and behaviour of marime organisms. Pergamon Press, Oxford, p 375-384 
Fong PP (1998) Zebra mussel spawning is induced in low concentrations of putative serotonin reuptake inhibitors. Biol Bull 194:143-149

Fong PP, Huminski PT, D'Urso LM (1998) Induction of parturition in fingernail clams (Sphaerium striatinum) by selective serotonin re-uptake inhibitors (SSRI's). J Exp Zool $280: 260-264$

Gibbons MC. Castagna M (1984) Serotonin as an inducer of spawning in six bivalve species. Aquaculture 40:189-191.

Gilbert MA (1978) Aspects of the reproductive cycle in Macoma balthica (Bivalvia). Nautilus 92:21-24.

Günther CP, Boysen-Ennen E, Niesel V, Hasemann C, Heuers J, Bittkau A, Fetzer I, Nacken $M$, Schlüter M, Jaklin S (1998) Observations of a mass occurrence of Macoma balthica larvae in high summer. J Sea Res 140:347-351

Harvey M, Vincent B (1989) Spatial and temporal variations of the reproduction cycle and energy allocation of the bivalve Macoma balthica (L.) on a tidal flat. J Exp Mar Biol Ecol 129:199-217

Hirai S, Kishimoto T, Kadam AL, Kanatani H, Koide SS (1988) Induction of spawning and oocyte maturation by 5 -hydroxitryptamine in the surf clam. J Exp Zool 245:318-321

Honkoop PJC, Van der Meer J (1997) Reproductive output of Macoma balthica populations in relation to wintertemperature and intertidal-height mediated changes of body mass. Mar Ecol Prog Ser 149:155-1.62

Honkoop PJC, Van der Meer J (1998) Experimentally induced effects of water temperature and immersion time on reproductive output of bivalves in the Wadden Sea. J Exp Mar Biol Ecol 220:227-246

Knowlton N (1993) Sibling species in the sea. Annu Rev Ecol Syst 24:189-216

Editorial responsibility: Otto Kinne (Editor).

Oldendorf/Luhe, Germany
Levitan DR (1988) Asynchronous spawning and aggregative behaviour in the sea urchin Diadema antillarum Philippi. In: Burke RD (ed) Echinoderm biology: proceedings of the sixth international echinoderm conference: Victoria Balkema, Rotterdam, p 181-186

Levitan DR (1993) The importance of sperm limitation to the evolution of egg size in marine invertebrates. Am Nat 141 517-536

Levitan DR, Sewall MA, Chia FS (1991) Kinetics of fertilization in the sea urchin Strongylocentrotus franciscanus interaction of gamete dilution, age, and contact time. Biol Bull 181:371-378

Loosanoff VL, Davis HC (1963) Rearing of bivalve mollusks In: Russell FS (ed) Advances in marine biology, Vol. 1 Academic Press, London, p 2-136

McClary D, Barker M (1998) Reproductive isolation? Interannual variability in the timing of reproduction in sympatric sea urchins, genus Pseudechinus. Invertebr Biol 117:75-93

Nichols FH, Thompson JK (1982) Seasonal growth in the bivalve Macoma balthica near the southern limits of its range. Estuaries 5:110-120

Pennington JT (1985) The ecology of fertilization of echinoid eggs: the consequence of sperm dilution, adult aggregation, and synchronous spawning. Biol Bull 169:417-430

Ram JL, Crawford GW, Walker JU, Morajes JJ, Patel N, Fong PP, Kyozuka K (1993) Spawning in the zebra mussel (Dreisenna polymorpha): activation by internal application of serotonin. J Exp Zool 265:587-598

Thompson JK, Nichols FH (1988) Food availability controls seasonal cycle of Macoma balthica (L.) in San Francisco Bay, California. J Exp Mar Biol Ecol 116:43-61

Submitted: January 22, 1999; Accepted: March 2, 1999

Proofs received from author(s): April 9, 1999 